\title{
PENGARUH KOMBINASI BEBERAPA MEDIA TERHADAP PERTUMBUHAN DAN PRODUKSI JAMUR KUPING \\ (Auricularia auriculaJ.)
}

\author{
Elmiwati $^{1}$, Nurlaila Sitepu ${ }^{1}$,Desvika Ariya Savitri ${ }^{2}$, \\ ${ }^{1}$ Dosen Program Studi, Pendidika Biologi STKIP Abdi Pendidikan Payakumbuh, Indonesia \\ 2Program Studi, Pendidika Biologi STKIP Abdi Pendidikan Payakumbuh, Indonesia \\ (Diterima 8 Mei 2015, disetujui 13 Juni 2015)
}

\section{ABSTRACT}

Ear fungus (Auricularia auricula J.) is a plant that has many benefits, but used as material consumption, mushroom is also beneficial for treating various kinds of diseases. The need and the benefits are so great mushroom makes a lot of people want to cultivate, but in cultivation there are several obstacles, such as lack of availability of teak sawdust as a growing medium. This study aims to determine the combined effect of media on growth and production plants mushroom (Auricularia auricula J.). The research was conducted at Jl. Sudirman, KelurahanPayolinyamTigo Koto di Baruah, KecamatanPayakumbuh Utara. from May to July 2016. The method used is experiment using a completely randomized design (CRD), with 5 treatments and 4 replications. Each treatment is A (control), B (sawdust 750g, coco 200g, husks 250g), C (sawdust 850g, coco 150g, husks 200g), D (sawdust 950g, coco 100g, husks 150g ), E (sawdust $1050 \mathrm{~g}, 50 \mathrm{~g}$ coconut husks, rice husks $100 \mathrm{~g}$ ). Observations were made on the number of fruit bodies perbaglog, and the wet weight of mushroom. Research results from the analysis using the $\mathrm{F}$ test.The results showed Award combination of growing media influence on the number of fruit bodies with Fhitung 11.77> Ftabel 4.89 (1\%), and the plant fresh weight mushroom with Fᄀhitung 6.587> 4.89 Ftabel (1\%). From the test results Fhitung using completely randomized design (CRD) can be proved that the administration of a combination of several media on the growth and production of mushroom (Auricularia auricula J.).

Keywords : Ear fungus, The growth, Production, and effect of several media

\begin{abstract}
ABSTRAK
Jamur kuping (Auricularia auricula J.) merupakan tanaman yang memiliki banyak manfaat, digunakan sebagai konsumsi bahan, jamur juga bermanfaat untuk mengobati berbagai macam penyakit. Kebutuhan dan manfaat yang jamur begitu besar membuat banyak orang ingin mengolah, tetapi dalam budidaya ada beberapa kendala, seperti kurangnya ketersediaan serbuk gergaji kayu jati sebagai media tumbuh. Penelitian ini bertujuan untuk mengetahui efek gabungan dari media pada pertumbuhan dan produksi tanaman jamur (Auricularia auricula J.). Penelitian ini dilakukan di Jl. Sudirman, Kelurahan Payolinyam Tigo Koto di Baruah, Kecamatan Payakumbuh Utara. dari Mei hingga Juli 2016. Metode yang digunakan adalah eksperimen menggunakan rancangan acak lengkap (RAL), dengan 5 perlakuan dan 4 ulangan. Setiap pengobatan A (kontrol), B (serbuk gergaji $750 \mathrm{~g}$, coco $200 \mathrm{~g}$, sekam $250 \mathrm{~g}$ ), C (serbuk gergaji $850 \mathrm{~g}$, coco $150 \mathrm{~g}$, sekam 200g), D (serbuk gergaji 950g, coco 100g, sekam 150g), E (serbuk gergaji 1050g, $50 \mathrm{~g}$ sabut kelapa, sekam padi $100 \mathrm{~g}$ ). Pengamatan dilakukan pada jumlah buah

*Penuliskorespondensi : Elmiwati, Nurlaila Sitepu, Desvika Ariya Savitri. Prodi

PendidikanBiologi STKIP Abdi Pendidikan Payakumbuh
\end{abstract}


Vol. 1, No. 1, 2015

Produksi Jamur Kuping

tubuh perbaglog, dan berat basah jamur. Hasil penelitian dari analisis menggunakan hasil $\mathrm{F}$ test.Menunjukkan pemberian kombinasi pengaruh media tanam pada jumlah badan buah dengan Fhitung 11,77>Ftabel 4,89 (1\%), dan tanaman jamur berat segar dengan F $\neg$ hitung 6,587> 4,89 Ftabel (1\%). Dari hasil uji Fhitung menggunakan rancangan acak lengkap (RAL) dapat dibuktikan bahwa pemberian kombinasi beberapa media terhadap pertumbuhan dan produksi jamur (Auricularia auricula J.).

Kata Kunci : Jamur kuping, pertumbuhan, produksi, dan kombinasi beberapa media.

\section{PENDAHULUAN}

Sejak zaman dahulu, jamur telah dikonsumsi sebagai bahan makanan yang memiliki rasa yang enak dan tekstur yang hampir mirip dengan daging. Bagi sebagian orang, jamur merupakan makanan mewah dan bernutrisi tinggi. Selain sebagai bahan makanan, jamur juga dapat dikonsumsi sebagai obat yang dapat menyembuhkan beberapa penyakit seperti kanker, diabetes, kolesterol, dan sebagainya. Jamur pangan atau disebut juga sebagai jamur konsumsi merupakan jamur yang biasa dijadikan bahan makanan dan dikonsumsi serta tidak mengandung racun bagi kesehatan. Beberapa jenis jamur ini dipetik dari hasil panen budidaya jamur dan ada pula dipetik dari alam liar. Seiring perkembangan zaman telah banyak ditemukan teknik pembudidayaan jamur guna memenuhi standar konsumsi kebutuhan jamur di masyarakat. Adapun jenis jamur yang banyak dikonsumsi antara lain adalah jamur merang (Volvariella volvaceae), jamur kayu seperti jamur kuping (Auricularia auricula J), dan beberapa jenis jamur tiram (Pleurotus sp)

Jamur kuping (Auricularia auricula J) merupakan jenis jamur kayu dari Kelas Heterobasidiomycetes. yang memiliki kandungan gizi dan nilai ekonomi yang tinggi.Pada awalnya, pemenuhan kebutuhan manusia terhadap jamur konsumsi hanya mengandalkan kemurahan alam. Dengan cara seperti ini, jumlah jamur yang didapatkan sangat terbatas hanya pada musim tertentu bisa diperoleh. Di Indonesia, jamur hanya tumbuh secara alami pada musim hujan. Inisiatif membudidayakan jamur konsumsi dilakukan saat kebutuhannya terus meningkat, sedangkan persediaan di alam semakin terbatas. 
Berkat pengamatan dan ketelitian mempelajari cara hidup nya, manusia berhasil membudidayakan jamur konsumsi untuk memenuhi kebutuhan yang meningkat setiap saat (Parjimo dan Agus.2008:13-14).Budidaya jamur merupakan salah satu cara yang efektif untuk membantu proses composting(pengomposan). Jamur adalah salah satu organisme non fotosintetik, tetapi memiliki beberapa enzim yang mampu mendegradasi senyawa-senyawa di atas menjadi senyawa yang lebih sederhana. Contoh enzim tersebut adalah selulase, hemiselulase dan lain-lain. Enzim ini sangat bermanfaat sekali dalam penguraian senyawa-senyawa yang terdapat di dalam sel tanaman menjadi senyawa-senyawa sederhana yang dapat dimanfaatkan oleh jamur. Oleh karena kemampuan jamur tersebut, maka salah satu alternatif pemanfaatan limbah pertanian yang efektif adalah dengan memanfaatkan limbah pertanian ini menjadi media pertumbuhan jamur. Keuntungan memanfaatkan limbah pertanian ini adalah: mengurangi limbah pertanian, meningkatkan pendapatan, dan meningkatkan nilai gizi masyarakat.

Limbah pertanian merupakan sampah yang baik mutunya sebagai kompos dan campuran pupuk. Selain sebagai kompos limbah pertanian yang kaya unsure karbon (C) dan nitrogen (N) misalnya sabut kelapa (Cocos nucifera). Dimana dapat memiliki nilai tambah lebih apabila digunakan sebagai media pertumbuhan jamur. Masyarakat pedesaan mengenal sabut kelapa sebagai pelengkap kayu bakar kemudian pengetahuan tentang manfaat sabut kelapa berkembang menjadi media tanaman hias, contohnya media tanaman angrek, bahan tekstil. Mengingat sulitnya para petani jamur untuk mendapatkan serbuk gergaji sebagai media pertumbuhan jamur, sabut kelapa(Cocos nucifera).

Sekam padi(Oryza sativa )merupakan limbah penggilingan padi yang belum dimanfaatkan secara optimal. Biasanya sekam padi hanya dimanfaatkan untuk membakar batu bata, padahal kandungan kimia dalam sekam banyak manfaatnya. Sekam padi merupakan lapisan keras yang meliputi kariopsis, terdiri dari belahan lemma dan palea yang saling bertautan. Pada proses penggilingan beras sekam akan terpisah dari penggilingan beras dan menjadi bahan sisa. Sekam padi memiliki unsur N (Nitrogen) sebanyak 1\% dan K (Kalium) 2\% yang sangat dibutuhkan dalam pertumbuhan tanaman. 
Vol. 1, No. 1, 2015

Produksi Jamur Kuping

Mengingat besarnya unsur-unsur yang dikandung sekam, maka sangat perlu sekali pemanfaatannya kembali di sektor pertanian. Disamping sebagai sumber hara, sekam juga sebagai bahan organik yang dapat mengurangi absorpsi $\mathrm{P}$ (phospor) pada tanah, sebab sekam mengandung silika yang cukup tinggi, yang akan mampu melepaskan phosfat.Kandungan kimia sekam padi terdiri dari lignin dan selulosa dapat membantu pertumbuhan jamur kuping yang mengandung mineral.

Adanya pengetahuan sabut kelapa dan sekam padi sebagai media pertumbuhan jamur kuping, peneliti berharap para petani jamur tidak kesulitan untuk budidaya jamur ini apabila terjadi kelangkaan serbuk gergaji. Selain itu, adanya potensi sabut kelapa dan sekam padi ini sebagai media pertumbuhan, tidak menutup kemungkinan sabut kelapa dan sekam padi ini juga dapat digunakan sebagai media pertumbuhan jamur kayu jenis lainnya.

Permasalahan penyebab produksi jamur kuping yang rendah cukup kompleks, namun pada penelitian ini akan membahas mengenai penerapan substrat alternatif selain serbuk gergaji kayu. Formula media tumbuh jamur kuping yang digunakan petani selalu sama setiap produksi yaitu serbuk gergaji kayu, bekatul dan kapur. Serbuk gergaji kayu di dapat dari pabrik limbah pengolahan kayu dan umum digunakan petani karena sesuai dengan tempat tumbuh jamur kayu, selain itu dianggap praktis dan sudah dikenal mengandung selulosa, hemiselulosa, dan lignin yang berguna bagi pertumbuhan jamur. Pengguna serbuk gergaji sebagai substrat tumbuh tidak selalu tersedia di setiap tempat usaha budidaya jamur, sehingga diperlukan alternatif substrat yang berpotensi dapat mengantikan atau dengan mengkombinasikan serbuk gergaji kayu dengan substrat lainnya seperti sabut kelapa dan sekam padi.

Menurut uraian di atas, serbuk gergaji kayu sebagai substrat tumbuh nya jamur kuping tidak selalu tersedia di setiap tempat usaha budidaya jamur, maka telah dilakukan penelitian mengenai Pengaruh kombinasi beberapa media terhadap pertumbuhan dan produksi jamur kuping (Auricularia auricula J.). 


\section{METODOLOGIPENELITIAN}

Penelitian ini dilakukan di Kelurahan Payolinyam Tigo Koto Dibaruah, Kecamatan Payakumbuh Utara, Kota Payakumbuh. Waktu penelitian pada bulan Mei sampai Juli 2016.

\section{A. Metode Penelitian}

Penelitian mengetahui Pengaruh kombinasi beberapa media terhadap pertumbuhan dan produksi jamur kuping (Auricularia auricula $\mathrm{J}$ ).

Dilakukan dengan metode eksperimen memakai Rancangan Acak Lengkap (RAL). Sebagai perlakuan adalah penggunaan sabut kelapa, dan sekam padi sebagai media tumbuh jamur kuping, selain serbuk gergaji. Penelitian terdiri atas 5 pelakuan kombinasi media tanam dengan 4 kali ulangan, sehingga total terdapat 20 baglog.

Komposisi media tumbuh terdiri dari lima komponen utama yaitu serbuk gergaji, sabut kelapa, bekatul, kapur, dan sekam padi, dengan total bobot per baglog 1200 gram.

1. Perlakuan A : kontrol

2. Perlakuan B : serbuk gergaji 750 gram, sabut kelapa 200 gram, sekam250 gram.

3. Perlakuan $\mathrm{C}$ : serbuk gergaji 850 gram, sabut kelapa 150 gram, sekam 200 gram.

4. Perlakuan D : serbuk gergaji 950 gram, sabut kelapa 100 gram, sekam150 gram.

5. Perlakuan E : serbuk gergaji 1050 gram, sabut kelapa 50 gram, sekam 100 gram.

Parameter Pengamatan

a. Jumlah badan buah

diamati, dihitung, dan dicatat jumlah badan buah jamur per-baglog (dinyatakan dalam angka) dalam panen pertama.

b. Berat basah

ditimbang, diamati, dan dicatat berat basah jamur perbaglog (dinyatakan dalam gram) dalam panen pertama. 


\section{Analisis Data}

Data pengamatan dianalisis dengan Rancangan Acak Lengkap (RAL). Pada taraf kepercayaan 1\% dan 5\%. Menurut Gomes (2007:13-14) menyertakan bahwa.

\section{HASIL DAN PEMBAHASAN}

Berdasarkan hasil penelitian yang telah dilakukan terhadap pengaruh kombinasi beberapa media terhadap pertumbuhan dan produksi jamur kuping (Auricularia auricula J.) dengan 5 perlakuan dan 4 kali ulangan, maka didapatkan hasil sebagai berikut:

1. Rata-rata jumlahbadanbuahtanamanjamurkuping (Auricularia auricula J.).

Dengan pemberian dosis beberapa kombinasi media tanam yang berbeda pada tiap perlakuan sehingga didapatkan rata-rata jumlah badan buah tanaman jamur kuping yang paling banyak dan yang paling sedikit dapat dilihat padaTabel IV.4.

Tabel IV.4 Rata-rata Jumlah Badan Buah Tanaman Jamur Kuping (Auricularia auricula J.).

\begin{tabular}{ccc}
\hline No & Perlakuan & $\begin{array}{c}\text { Jumlah Rataan Badan Buah } \\
\text { Tanaman Jamur Kuping }\end{array}$ \\
\hline 1 & A (Kontrol) & 10,50 \\
2 & B (serbuk gergaji 750g, sabut kelapa \\
200g, sekam 250g) & 1,50 \\
3 & C (serbuk gergaji 850g, sabut kelapa \\
& $\begin{array}{c}\text { 150g, sekam 150g) } \\
4\end{array}$ & 2,50 \\
& $\begin{array}{c}\text { D (serbuk gergaji 950g, sabut kelapa } \\
\text { 100g, sekam 150g) }\end{array}$ & 3,00 \\
5 & $\begin{array}{c}\text { E (serbuk gergaji 1050g, sabut } \\
\text { kelapa 50g, sekam 100g) }\end{array}$ & 3,50 \\
\hline
\end{tabular}

Dari Tabel IV.4 diperoleh jumlah badan buah tanaman jamur kuping yang paling banyak adalah pada perlakuan A dengan jumlah 42 badan buah, sedangkan jumlah badan buah yang paling sedikit diperoleh pada perlakuan B dengan jumlah 6 badan buah.

Hasil penelitian ini kemudian dianalisis dengan menggunakan analisis sidik ragam untuk mengetahui pengaruh pemberian kombinasi beberapa media tanaman 
terhadap jumlah badan buah tanaman jamur kuping. Hasil analisis sidik ragam tersebut dapat dilihat pada Tabel IV.5

Tabel IV.5 SidikRagam RAL PengamatanJumlahBadanBuahTanamanJamurKuping (Auricularia auricula J.).

\begin{tabular}{ccccccc}
\hline $\begin{array}{c}\text { Sumber } \\
\text { Keragaman }\end{array}$ & $\begin{array}{c}\text { Derajat } \\
\text { Bebas }\end{array}$ & $\begin{array}{c}\text { Jumlah } \\
\text { Kuadrat }\end{array}$ & $\begin{array}{c}\text { Kuadrat } \\
\text { Tengah }\end{array}$ & $\mathbf{F}_{\text {hitung }}$ & \multicolumn{2}{c}{$\mathbf{F}_{\text {tabel }}$} \\
\hline Perlakuan & 4 & 207,2 & 51,8 & $11,77 *$ & 3,06 & 4,89 \\
Galat & 15 & 66 & 4,4 & & & \\
Umum & 19 & 273,2 & & & &
\end{tabular}

Keterangan: * Berbedanyatapada $1 \%$

Hasil analisis sidik ragam dengan uji $F_{\text {hitung }}$ pada taraf $1 \%$ didapatkan $\mathrm{F}_{\text {hitung }}$ $11,77>4,89 \mathrm{~F}_{\text {tabel }}(1 \%)$ yang berarti pemberian kombinasi beberapa media tanaman berpengaruh sangat nyata terhadap jumlah badan buah tanaman jamur kuping. Rata-rata jumlah badan buah tanaman jamur kuping dapat dilihat pada grafik IV.1

Grafik IV.1 Rata-rata JumlahBadanBuahTanamanJamurKuping

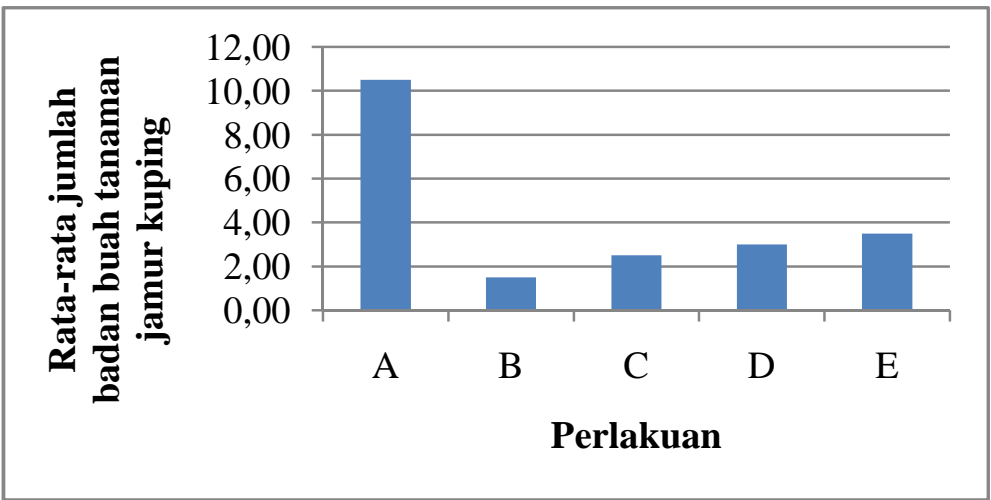

Dari grafik IV.1 dapat dilihat setiap perlakuan didapatkan rata-rata jumlah badan buah berbeda-beda, rata-rata jumlah badan buah yang paling tinggi adalah pada perlakuan A (kontrol) dengan rata-rata jumlah badan buah 10,50.

\section{Berat Basah Tanaman Jamur Kuping (Auricularia auricula J.).}

Tanaman jamur kuping dipanen pada umur 47 hari, pengamatan berat basah tanaman jamur kuping dapat dilihat pada lampiran 3 halaman 42. Untuk lebih jelasnya hasil berat basah tanaman jamur kuping (Auricularia auricula J.) perpolibag dapat dilihat pada Tabel IV.6. 
Tabel IV.6 hasil rata-rata Pengamatan Berat Basah Tanaman Jamur Kuping (Auricularia auricula J.).

\begin{tabular}{|c|l|c|}
\hline No & \multicolumn{1}{|c|}{ Perlakuan } & \multicolumn{1}{|c|}{$\begin{array}{c}\text { Jumlah Rataan Berat Basah } \\
\text { Tanaman Jamur Kuping }\end{array}$} \\
\hline 3 & $\begin{array}{l}\text { A (Kontrol) } \\
\text { B (serbuk gergaji 750g, sabut kelapa } \\
\text { 200g, sekam 250g) }\end{array}$ & 362,50 \\
4 & $\begin{array}{l}\text { C (serbuk gergaji 850g, sabut kelapa } \\
\text { 150g, sekam 150g) }\end{array}$ & 20,00 \\
5 & $\begin{array}{l}\text { D (serbuk gergaji 950g, sabut kelapa } \\
\text { 100g, sekam 150g) } \\
\text { E (serbuk gergaji 1050g, sabut } \\
\text { kelapa 50g, sekam 100g) }\end{array}$ & 52,50 \\
\hline
\end{tabular}

Dari pengamatan berat basah tanaman jamur kuping (Aricularia auricula J.) rata-rata berat basah tertinggi adalah pada perlakuan A (Kontrol) dengan rata-rata yang diperoleh $362,5 \mathrm{~g}$, sedangkan rata-rata berat basah terendah adalah pada perlakuan B (serbuk gergaji 750g, sabut kelapa 200g, sekam 250g) dengan ratarata yang diperoleh $20 \mathrm{~g}$.

Hasil penelitian ini kemudian dianalisis dengan menggunakan analisis sidik ragam untuk mengetahui pengaruh pemberian kombinasi media tanaman terhadap berat basah tanaman jamur kuping. Hasil analisis sidik ragam tersebut dapa dilihat pada Tabel IV.7

Tabel IV.7 Sidik Ragam RAL Pengamatan Berat Basah Tanaman Jamur Kuping (Auricularia auricula J.).

\begin{tabular}{ccccccc}
\hline $\begin{array}{c}\text { Sumber } \\
\text { Keragaman }\end{array}$ & $\begin{array}{c}\text { Derajat } \\
\text { Bebas }\end{array}$ & $\begin{array}{c}\text { Jumlah } \\
\text { Kuadrat }\end{array}$ & $\begin{array}{c}\text { Kuadrat } \\
\text { Tengah }\end{array}$ & $\mathbf{F}_{\text {hitung }}$ & \multicolumn{2}{c}{$\mathbf{F}_{\text {tabel }}$} \\
\hline Perlakuan & 4 & 301750 & 75437,5 & $6,58^{*}$ & 3,06 & 4,89 \\
Galat & 15 & 98705 & 6580,3 & & & \\
Umum & 19 & 4004455 & & & & \\
\hline
\end{tabular}

Keterangan: * Berbeda nyata pada 5\%

Dari hasil analisis sidik ragam berat basah tanaman jamur kuping (Auricularia auricula J.) setelah dianalisis dengan uji F pada taraf 5\% (lampiran 3 halaman 42). Diperoleh $\mathrm{F}_{\text {tabel }}(5 \%) 3,06<6,58 \mathrm{~F}_{\text {hitung }}$ yang berarti pemberian 
kombinasi beberapa media tanam berpengaruh nyata terhadap berat basah tanaman jamur kuping (Auricularia auricula J.) pada taraf 5\%. Rata-rata jumlah berat basah Tanaman jamur kuping dapat dilihat pada Grafik IV.2

Grafik IV.2 Rata-rata Jumlah Berat Basah Tanaman Jamur Kuping

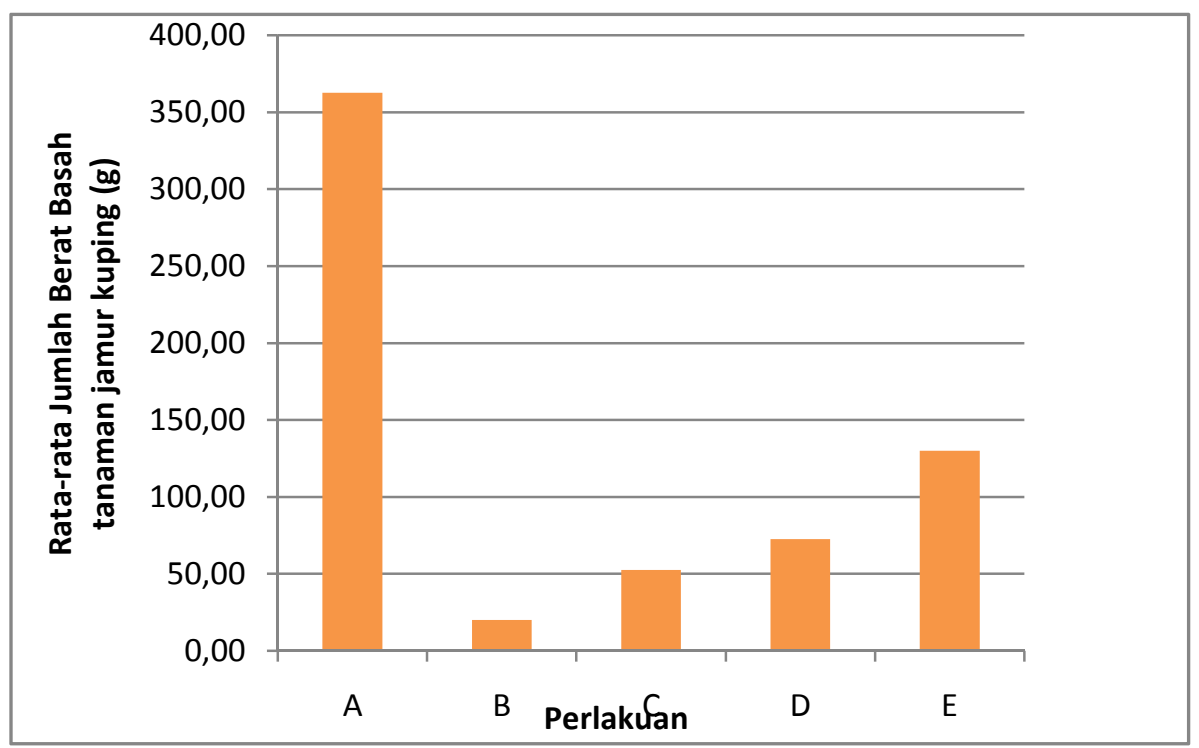

Dari grafik IV.2 dapat dilihat setiap perlakuan didapatkan rata-rata jumlah berat basah berbeda-beda, rata-rata jumlah berat basah yang paling tinggi adalah pada perlakuan A (kontrol) dengan rata-rata jumlah badan buah 362,50g.

\section{Pembahasan}

Berdasarkan penelitian yang telah dilakukan pada pemberian kombinasi beberapa media tanam terhadap pertumbuhan dan produksi tanaman jamur kuping (Auricularia auricula J.), dengan pemberian dosis yang berbeda setiap perlakuan.

Pada pengamatan jumlah badan buah tanaman jamur kuping (Auricularia auricula J.) setelah dilakukan analisis uji $\mathrm{F}$ didapatkan $\mathrm{F}_{\text {hitung }} 11,77>4,89 \mathrm{~F}_{\text {tabel }}$ (1\%) sehingga dapat disimpulkan bahwa pemberian kombinasi bebrapa media tanam berpengaruh terhadap jumlah badan buah tanaman jamur kuping (Auricularia auricula J.) dapat dilihat pada lampiran 2 halaman 39.

Pada perlakuan B ulangan 2, perlakuan C ulangan 1, perlakuan D ulangan 4, serta perlakuan E ulangan 2, badan buah tidak muncul, yang disebabkan oleh 
Vol. 1, No. 1, 2015

Produksi Jamur Kuping

Pengaruh Kombinasi Beberapa Media Terhadap Pertumbuhan Dan

ketidak sempurnanya proses sterilisasi pada media itu sehingga mengakibatkan matinya miselium yang akan tumbuh menjadi badan buah.

Sedangkan pada pengamatan berat basah tanaman jamur kuping (Auricularia auricula J.) dosis kombinasi beberapa media tanam memberikan pengaruh terhadap berat basah tanaman jamur kuping, karena $F_{\text {hitung }} 6,587>3,06$ $F_{\text {tabel }}(5 \%)$. Sehingga dapat disimpulkan pemberian kombinasi beberapa media tanam berpengaruh terhadap berat basah tanaman jamur kuping (Auricularia auricula J.). dapat dilihat pada lampiran 4 halaman 43.

Pada perlakuan A memiliki rata-rata berat basah yaitu 362,5gr, perlakuan B memiliki rata-rata yaitu $20 \mathrm{gr}$, perlakuan C memiliki rata-rata $52,5 \mathrm{gr}$, perlakuan D memiliki rata-rata $72,5 \mathrm{gr}$, dan perlakuan E memiliki rata-rata $130 \mathrm{gr}$. Menurut penelitian Sutarman dalam Resi (2015:33) menyatakan bahwa panen yang menggunakan media tambahan lain akan menggangu berat basah pada pertumbuhan jamur, karena memiliki sedikit kandungan lignin yang terdapat pada media lain.

Pada saat penelitian berlangsung ada beberapa tanaman jamur kuping yang mati yaitu pada perlakuan B2, perlakuan $\mathrm{C}$ 1, perlakuan $\mathrm{D} 4$, dan perlakuan E2. Matinya tanaman pada perlakuan tersebut diakibatkan oleh beberapa hama dan penyakit. Yang mana hama dan penyakit yang ditemukan yaitu siput, laba-laba, dan tikus. Hal itu terjadi dikarenakan kurang telitinya peneliti terhadap sterilisasi pada pemeliharaan dikumbung jamur kuping.

\section{KESIMPULAN DAN SARAN}

\section{A. Kesimpulan}

Berdasarkan penelitian yang telah dilakukan dapat diambil kesimpulan bahwa terdapat pengaruh pemberian kombinasi beberapa media tanam terhadap pertumbuhan dan produksi jamur kuping (Auricularia auricula J), yaitu jumlah badan buah dianalisis sidik ragam dengan uji $\mathrm{F}_{\text {hitung }}$ pada taraf $1 \%$ didapatkan $\mathrm{F}_{\text {hitung }} 11,77>4,89 \mathrm{~F}_{\text {tabel}}$, dan juga berat basah yang dianalisis sidik ragam dengan uji $\mathrm{F}_{\text {hitung }}$ pada taraf $1 \%$ didapatkan $\mathrm{F}_{\text {hitung }} 6,58>4,89 \mathrm{~F}_{\text {tabel. }}$

\section{B. Saran}


Hasil penelitian ini sangat bermanfaat untuk dijadikan alternatif pemberian media yang membantu pertumbuhan dan produksi jamur kuping. Dari hasil penelitian ini dapat disarankan :

1. Untuk membudidayakan jamur kuping (Auricularia auricula J.) ini, hendaknya memiliki tempat yang khusus atau yang tidak digabung dengan jamur lain, agar pertumbuhannya sempurna.

2. Sebelum memasukkan bibit kedalam baglog hendaknya mensterilkan ruangan agar tidak ada bakteri yang menimbulkan kegagalan pertumbuhan dan produksi jamur kuping (Auricularia auricula J.)

3. Petani dapat menggunakan kombinasi media serbuk gergaji kayu jati dengan sekam dan sabut kelapa.

\section{DAFTAR PUSTAKA}

Arif, A. dan D. Sanusi, 2001. Pengembangan pengolahan kayu jati (Tectona grandis L.)

Balai Pengkajian Teknologi Pertanian (BPTP). 2013. Laboratorium Tanah. Karang Ploso. Malang.

Departemen Pertanian. 2007. Budidaya jamur kuping (Auricularia sp.). Direktorat jendra hortikultura, Direktorat budidaya tanaman sayuran dan biofarmaka.

Djuariah, D dan E. Sumiati. 2008. Penampilan Fenotipik Tujuh Spesies Jamur Kuping ( Auricularia spp.) di Dataran Tinggi Lembang. J. Hort. 18(3):255260.

Irianto, Yuli, A. Susilowati, dan Wiryanto. 2004. Pertumbuhan, Kandungan Protein, dan Sianida Jamur Kuping (Auricularia polytricha) pada Medium Tumbuh Serbuk Gergaji dan Ampas Tapioka dengan Penambahan Pupuk Urea. Bioteknologi 5 (2): 43-50.

Maryati, Sri. 2009. Laporan Magang Budidaya Jamur Kuping (Auricularia auriculajudae(Linn.) Schroter). Surakarta: UPTD. Balai Pengembangan dan Promosi Tanaman Pangan Hortikultura..

Muchroji dan Cahyana Y.A, 2010 . Jenis - jenis jamur kuping (Auricularia auricula J). Jakarta: Penebar Swadaya

, 2008 . Budidaya jamur kuping (Auricularia auricula J). Jakarta: Penebar Swadaya

Parjimo dan Agus andoko.2007. Pemenuhan kebutuhan manusia terhadap jamur konsumsi. Jakarta: Agro Media Pustaka

Sari, Resi Permata. 2015. "Pengaruh penggunaan beberapa media tanam terhadap pertumbuhan jamur tiram putih (Pleorotus ostreatus L.)”. Payakumbuh: Lembaga Penelitian.

Sangun, Enisar. 2010. “ Usaha Enam Jenis jamur skala rumah tangga”. Jakarta: percetakan berkat Jaya.

Sumiati, E. 2008. "Jenis Suplemen Substrat Untuk Meningkatkan Produksi Tiga Strain Jamur Kuping”. J. Hort. 19(1):75-88. 
Vol. 1, No. 1, 2015

Pengaruh Kombinasi Beberapa Media Terhadap Pertumbuhan Dan

Produksi Jamur Kuping

Djarijjah, Nunung Marlina, dan Abbas Siregar Djarijjah. 2001. Budidaya Jamur Kuping Pembibitan dan Pemeliharaan. Yogyakarta: Kanisius 